\title{
Coexistence of EZH2, NOTCH1, IL7R, and PHF6 Mutations in Adult T-cell Acute Lymphoblastic Leukemia
}

\author{
Erişkin T-hücre Akut Lenfoblastik Lösemi'sinde EZH2, NOTCH1, IL7R ve PHF6 \\ Mutasyonlarının Birlikteliği
}

\author{
Xilian Zhou ${ }^{1}$, Yan Gu${ }^{1}$, Qi Han ${ }^{1}$, Mario Soliman², Chunhua Song ${ }^{2}$, Zheng Ge ${ }^{1}$ \\ ${ }^{1}$ Zhongda Hospital, Medical School of Southeast University Department of Hematology Nanjing, China \\ ${ }^{2}$ Pennsylvania State University, Department of Pediatrics, Pennsylvania, USA
}

To the Editor,

Enhancer of zestehomolog 2 (EZH2) mutations are reported in solid tumors $[1,2,3]$ as well as leukemia, and they are most commonly detected in early T-cell precursor acute lymphoblastic leukemia (ETP-ALL) $[4,5,6,7,8]$, which is an extraordinarily aggressive malignancy of enigmatic genetic basis [9]. We screened EZH2 mutations in 146 Chinese adult ALL patients, among which $24.7 \%(36 / 146)$ cases were T-cell acute lymphoblastic leukemia (T-ALL) and 12.9\% (4/31) T-ALL cases were identified as ETP-ALL. We found three EZH2 mutations in two patients with T-ALL. One patient had Mu\#1:D730fs*1, a truncation mutation that was previously reported in acute myeloid leukemia, and the another patient had two new EZH2 mutations, Mu\#2:K466T and Mu\#3:T467fs* $>3$ (Figure 1). We also screened the mutations in other genes (Table 1). Strikingly, the EZH2 mutations coexisted with mutations of NOTCH1, ILZR, and PHF6 in the two patients and they responded poorly to chemotherapy and experienced difficult clinical histories and inferior outcomes (Table 1). Patient 1 was diagnosed with T-ALL with myeloid expression based on his bone marrow (BM) smear and immunophenotypes (Table 1). With the first inductive therapy (Table 1), the patient achieved complete remission (CR) with $0.1 \%$ blasts in the peripheral blood (PB) and $0.8 \%$ in BM. One year later, the patient relapsed with $90.4 \%$ lymphoblasts in the $\mathrm{BM}$ and $1.0 \%$ in the $\mathrm{PB}$, and $\mathrm{CR}$ was achieved after the first chemotherapy. During the following treatment, he underwent an intramedullary and an extramedullary relapse infiltrating his left tonsil and then endured three more relapses. On the fifth relapse, the BM blast rate was 50.4\%. Although the patient was treated with nelarabine, no CR was achieved in the subsequent treatments. Even though the BM blast rate was $5.2 \%$, the patient died of infection during the BM suppression period after he received the last chemotherapy. We examined the $E Z H 2$ mutational status in the BM samples of the $1^{\text {st }}$ relapse, $5^{\text {th }}$ relapse, and 6 weeks after his $5^{\text {th }}$ relapse; the $E Z H 2$ and NOTCH1 mutation status remained the same as in the first diagnosis even after the nelarabine treatment (Figure 1D). Patient 2 presented with $80.0 \%$ lymphoblasts in the PB and $78.0 \%$ blasts in the

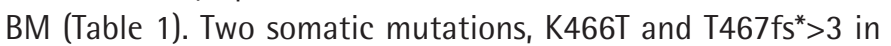

A

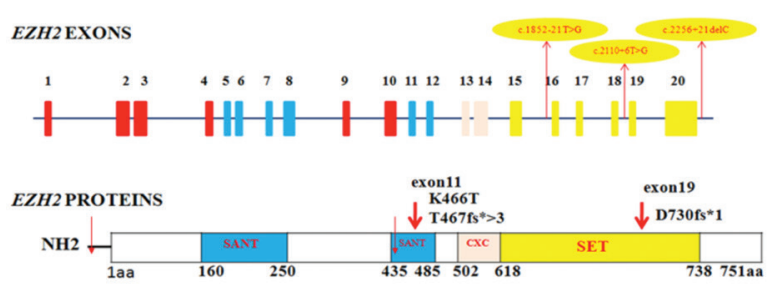

B

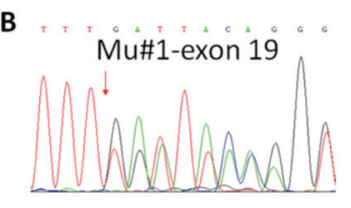

D

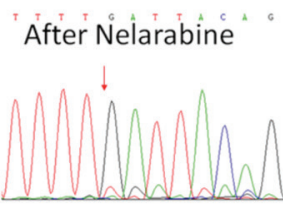

C

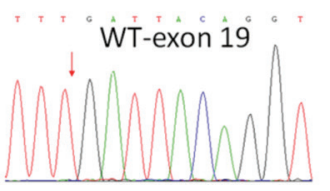

E

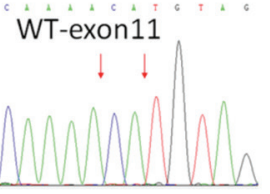

$\mathbf{F}$

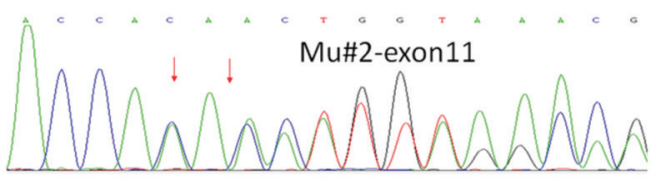

Figure 1. Location and sequencing data of the $E Z H 2$ mutations. A) Mutation 1 (Mu\#1:D730fs*1), located in exon 19, is a frame shift-creating insertion; on the protein level, it leads to a truncated protein with a length of 731 amino acids, which is located in the conserved catalytic SET domain(amino acids 618731). This domain is critical for the methyltransferase activity of $E Z H 2$. The other two mutations (Mu\#2:K466T; Mu\#3:T467fs* $>3$ ) located within exon 11 are anon-synonymous single-nucleotide substitution and a frame shift-creating deletion, respectively; on the protein level, they result in the substitution of EZH2 lysine466 to tyrosine and a truncation of the $E Z H 2$ protein, respectively. Mu\#2 and Mu\#3 are novel EZH2 mutations; both of them are located in the SANT domain of the EZH2 protein (amino acids 435-485), which is known to be incharge of the DNA binding. Mu\# 1 was detected in patient 1 and the other two in patient 2. Blue, pink, and yellow bars correspond to exons encoding the SANT domains, the cysteine-rich CXC domain, and the SET domain, respectively. The red arrows show EZH2 mutations. B-F) The direct sequencing data of EZH2 mutations $(B, D, F)$ and wildtype (C, E). B: c.2187_2188insT p.D730fs*1; C: EZH2 exon 19 wildtype; D: Mu\# 1 after nelarabine treatment; E: EZH2 exon 11 wildtype; F: c.1397A>C; 1399delA p.K466T; T467fs* $>3$. 


\begin{tabular}{|c|c|c|c|c|c|}
\hline \multicolumn{4}{|c|}{ 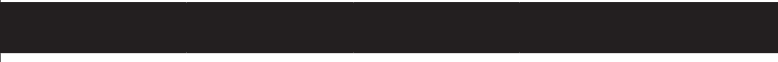 } & Patient 1 & Patient 2 \\
\hline \multicolumn{4}{|c|}{ Age (years)/Sex } & 49/Male & 41/Female \\
\hline \multicolumn{4}{|c|}{ WBC, $\times 10^{9} / L$} & 9.7 & 64.9 \\
\hline \multicolumn{4}{|c|}{ Hemoglobin $(\mathrm{g} / \mathrm{L})$} & 128 & 71 \\
\hline \multicolumn{4}{|c|}{ Platelets $\left(\times 10^{9} / \mathrm{L}\right)$} & 96 & 38 \\
\hline \multicolumn{4}{|c|}{ BM/PB blasts ( $\%)$} & $50.4 / 0$ & 78.0/80.0 \\
\hline \multicolumn{4}{|c|}{ Mutation screening } & Patient 1 (nucleotide/mutant ID) & Patient 2 (nucleotide/mutant ID) \\
\hline Gene & $\begin{array}{l}\text { ALL (\%) } \\
(\mathrm{n}=146)\end{array}$ & $\begin{array}{l}\text { T-ALL }(\%) \\
(n=36)\end{array}$ & Exon & & \\
\hline \multirow[t]{2}{*}{$E Z H 2$} & \multirow[t]{2}{*}{1.4} & \multirow[t]{2}{*}{5.6} & Exon 19 & 2187_2188insT/COSM52999 & \\
\hline & & & Exon 11 & & 1397A >C / (new) 1399delA / (new) \\
\hline \multirow[t]{2}{*}{ NOTCH1 } & \multirow[t]{2}{*}{75.0} & \multirow[t]{2}{*}{74.4} & Exon 34 & 7541_7542deICT/COSM13065 & 7329_7330delinsCCCA / COSM5752017 \\
\hline & & & Exon 27 & & $5033 \mathrm{~T}>\mathrm{A} / \mathrm{COSM} 21907$ \\
\hline PHF6 & 33.3 & 33.3 & Exon 2 & 134delG+insCC/(new) & \\
\hline \multirow[t]{4}{*}{ IL7R } & \multirow[t]{4}{*}{3.4} & \multirow[t]{4}{*}{9.7} & Exon 2 & 197T>C/COSM149813 & 197T>C / COSM149813 \\
\hline & & & Exon 4 & $254 \mathrm{G}>\mathrm{A} / \mathrm{COSM} 149814$ & $254 \mathrm{G}>\mathrm{A} / \mathrm{COSM} 149814$ \\
\hline & & & Exon 6 & & 755_756ins9 / (new) \\
\hline & & & Exon 8 & 1066A>G/rs3194051 & \\
\hline FBXW7 & 4.6 & 16.7 & Exons 5-12 & Negative & Negative \\
\hline PTEN & 12.1 & 12.5 & Exons 1-9 & Negative & Negative \\
\hline CRLF2 & 27.7 & 17.2 & Exons 1-6 & Negative & $33 \mathrm{C}>\mathrm{G} /$ (new) \\
\hline SH2B3 & 21.2 & 16.0 & Exons 1-7 & Negative & Negative \\
\hline \multirow[t]{2}{*}{ DNM2 } & \multirow[t]{2}{*}{14.7} & \multirow[t]{2}{*}{15.2} & Exon 6 & $789 \mathrm{G}>\mathrm{A} / \mathrm{rs} 199976453$ & \\
\hline & & & Exon 20 & 2139T>C/rs2229920 & 2139T>C / rs2229920 \\
\hline TP53 & 6.9 & 11.1 & Exons 4-9 & Negative & Negative \\
\hline$J A K 1$ & 7.0 & 14.8 & Exons $13,14,16-19$ & Negative & Negative \\
\hline \multicolumn{4}{|c|}{ Immunophenotype (\%) } & Patient 1 & Patient2 \\
\hline \multicolumn{4}{|l|}{ CD34 } & $64.3 \%$ & $91 \%$ \\
\hline \multicolumn{4}{|l|}{ CD13 } & $28 \%$ & $98 \%$ \\
\hline \multicolumn{4}{|l|}{ CD33 } & $97 \%$ & $90 \%$ \\
\hline \multicolumn{4}{|l|}{ CD3 } & $32.5 \%$ & - \\
\hline \multicolumn{4}{|l|}{ CD5 } & $99.4 \%$ & $38 \%$ \\
\hline CD7 & & & & $99.5 \%$ & $63 \%$ \\
\hline Hepatom & & & & Negative & Negative \\
\hline Splenom & & & & Negative & Positive \\
\hline Lymphad & athy & & & Negative & Positive \\
\hline IKZF1 del & & & & Negative & Negative \\
\hline $\mathrm{BCR} / \mathrm{ABL}$ & & & & Negative & Negative \\
\hline Complex & otype & & & Negative & Negative \\
\hline Treatmen & & & & $\begin{array}{l}\text { 1xHyperCVAD+2xIDA+FLAG+1xFLAG } \\
+1 \times B F M 2002-H R-1+1 \times M O A P+4 x C A \\
\text { G+Methylprednisolone+1xICE+3xNel } \\
\text { arabine+1xDecitabine+0.5xCAG }\end{array}$ & $\begin{array}{l}\text { 1xHyper-CVAD+1xMA; no nelarabine } \\
\text { treatment }\end{array}$ \\
\hline $1^{\text {st }} \mathrm{CR}$ tim & & & & 42 days to achieve $C R$ & Unknown \\
\hline Relapse $t$ & after CR1 & & & 21 months & Unknown \\
\hline Total rela & ime & & & 5 & Lost to follow-up \\
\hline Outcome & & & & Death & Lost to follow-up \\
\hline
\end{tabular}


EZH2 exon 11, were detected in her BM sample (Figure 1). No CR was achieved with the first induction therapy. Finally, the patient was administered methotrexate and cytarabine and endured a long period of BM suppression. Unfortunately, the patient was lost to follow-up. Our data indicated the oncogenic and poor prognostic effect of EZH2 mutations on T-ALL. The coexistence of $E Z H 2$ mutations with mutations in the NOTCH1, $P H F 6$, and IL7R genes suggested a new mechanism underlying the tumorigenesis of EZH2 mutations in T-ALL. T-ALL and particularly ETP-ALL still have largely negative outcomes. In the past years, the effect of the use of nelarabine for relapsed and refractory T-ALL seemed to be negligible [10]. In our cohort, the first patient's relapse, even after nelarabine treatment, revealed the insensitivity of patients with multiple mutations to such treatment. Moreover, our case report suggested that the gene mutations may be the cause of the failure of the drug treatment and emphasized the importance of developing more effective therapies as well as more active and tailored treatments for aggressive T-ALL.

\section{Acknowledgment}

This work was supported in part by the National Natural Science Foundation of China (81270613,30973376); Jiangsu Province Key Medical Talents (RC2011077); the Scientific Research Foundation for the Returned Overseas Chinese Scholars; State Education Ministry (39 $\left.{ }^{\text {th }}\right)$; China Postdoctoral Science Foundation (20090461134); special grade of financial support from the China Postdoctoral Science Foundation (201003598); the Six Great Talent Peak Plan of Jiangsu (2010-WS-024); the Nanjing Municipal Bureau of Personnel (2009); the Fundamental Research Funds for the Central Universities (2242017K40271, 2242016K40143) (ZG); and the Milstein Medical Asian American Partnership Foundation Research Project Award in Hematology (2017) (ZG and CS).

Keywords: EZH2, Adult, T-cell, Acute lymphoblastic leukemia

Anahtar Sözcükler: EZH2, Erişkin, T-hücre, Akut lenfoblastik lösemi

Conflict of Interest: The authors of this paper have no conflicts of interest, including specific financial interests, relationships, and/or affiliations relevant to the subject matter or materials included.

\section{References}

1. Wassef M, Michaud A, Margueron R. Association between EZH2 expression, silencing of tumor suppressors and disease outcome in solid tumors. Cell Cycle 2016;15:2256-2262.

2. Gonzalez ME, Moore HM, Li X, Toy KA, Huang W, Sabel MS, Kidwell KM, Kleer CG. EZH2 expands breast stem cells through activation of NOTCH1 signaling. Proc Natl Acad Sci U S A 2014;111:3098-3103.

3. Katoh M. Mutation spectra of histone methyltransferases with canonical SET domains and EZH2-targeted therapy. Epigenomics-UK 2016;8:285-305.

4. Ernst T, Pflug A, Rinke J, Ernst J, Bierbach U, Beck JF, Hochhaus A, Gruhn B. A somatic $E Z H 2$ mutation in childhood acute myeloid leukemia. Leukemia 2012;26:1701-1703.

5. Guglielmelli $P$, Biamonte $F$, Score J, Hidalgo-Curtis $C$, Cervantes $F$, Maffioli M, Fanelli T, Ernst T, Winkelman N, Jones AV, Zoi K, Reiter A, Duncombe A, Villani L, Bosi A, Barosi G, Cross NC, Vannucchi AM. EZH2 mutational status predicts poor survival in myelofibrosis. Blood 2011;118:5227-5234.

6. Nikoloski G, Langemeijer SM, Kuiper RP, Knops R, Massop M, Tönnissen ER, van der Heijden A, Scheele TN, Vandenberghe $P$, de Witte $T$, van der Reijden $\mathrm{BA}$, Jansen JH. Somatic mutations of the histone methyltransferase gene EZH2 in myelodysplastic syndromes. Nat Genet 2010;42:665-667.

7. Morin RD, Johnson NA, Severson TM, Mungall AJ, An J, Goya R, Paul JE, Boyle M, Woolcock BW, Kuchenbauer F, Yap D, Humphries RK, Griffith OL, Shah S, Zhu H, Kimbara M, Shashkin P, Charlot JF, Tcherpakov M, Corbett R, Tam A, Varhol R, Smailus D, Moksa M, Zhao Y, Delaney A, Qian H, Birol I, Schein J, Moore R, Holt R, Horsman DE, Connors JM, Jones $S$, Aparicio $S$, Hirst M, Gascoyne RD, Marra MA. Somatic mutations altering EZH2 (Tyr641) in follicular and diffuse large B-cell lymphomas of germinal-center origin. Nat Genet 2010;42:181-185.

8. Zhang J, Ding L, Holmfeldt L, Wu G, Heatley SL, Payne-Turner D, Easton J, Chen X, Wang J, Rusch M, Lu C, Chen SC, Wei L, Collins-Underwood JR, Ma J, Roberts KG, Pounds SB, Ulyanov A, Becksfort J, Gupta P, Huether R, Kriwacki RW, Parker M, McGoldrick DJ, Zhao D, Alford D, Espy S, Bobba KC, Song G, Pei D, Cheng C, Roberts S, Barbato MI, Campana D, Coustan-Smith E, Shurtleff SA, Raimondi SC, Kleppe M, Cools J, Shimano KA, Hermiston ML, Doulatov S, Eppert K, Laurenti E, Notta F, Dick JE, Basso G, Hunger SP, Loh ML, Devidas M, Wood B, Winter S, Dunsmore KP, Fulton RS, Fulton LL, Hong $X$, Harris CC, Dooling DJ, Ochoa K, Johnson KJ, Obenauer JC, Evans WE, Pui CH, Naeve CW, Ley TJ, Mardis ER, Wilson RK, Downing JR, Mullighan CG. The genetic basis of early T-cell precursor acute lymphoblastic leukaemia. Nature 2012;481:157-163.

9. Schäfer V, Ernst J, Rinke J, Winkelmann N, Beck JF, Hochhaus A, Gruhn B, Ernst T. EZH2 mutations and promoter hypermethylation in childhood acute lymphoblastic leukemia. J Cancer Res Clin Oncol 2016;142:1641-1650.

10. Litzow MR, Ferrando AA. How I treat T-cell acute lymphoblastic leukemia in adults. Blood 2015;126:833-841. 